\title{
AVALIAÇÃO VISUAL DA APRENDIZAGEM: UMA ALTERNATIVA PARA ALUNOS SURDOS
}

ELIFAS LEVI SILVA

ELAYNE KANASHIRO

\section{RESUMO}

Este artigo apresenta a avaliação visual, uma proposta bilíngue a alunos surdos do ensino médio que vai ao encontro da política linguística e educacional inclusiva. Essa avaliação utiliza, além do texto verbal, o não verbal, incluindo elementos visuais, como imagens referentes aos conteúdos abordados, e proporciona isso ao aluno surdo em sua própria língua natural, a Língua Brasileira de Sinais. Foram observados e considerados aspectos relacionados a alunos surdos de grau profundo e filhos de pais ouvintes. 0 registro das observações foi feito por meio de entrevistas gravadas em vídeo-Libras e a análise dos dados se constituiu como uma investigação através da observação inicial da intérprete de Libras e depois do professor. Constatou-se que essa avaliação reduz os sentimentos negativos reforçados pela avaliação escrita, favorece a autonomia, a percepção de competência e de pertencimento, auxiliando na motivação do processo de ensino e aprendizagem.

PALAVRAS-CHAVE DEFICIENTE dA AUdIÇÃo • LIBRAS • EDUCAÇÃO INCLUSIVA • AVALIAÇÃO DA APRENDIZAGEM. 


\section{RESUMEN}

Este artículo presenta la evaluación visual, una propuesta bilingüe a alumnos sordos de la educación media relativa a la política lingüística y educacional inclusiva. Esta evaluación utiliza, además del texto verbal, el no verbal, incluyendo elementos visuales, como imágenes referentes a los contenidos abordados, y lo proporciona al alumno sordo en su propio idioma natural, la Lengua Brasileña de Signos (Libras). Se observaron y consideraron aspectos relacionados con alumnos sordos de grado profundo y a hijos de padres oyentes. El registro de las observaciones se efectuó por medio de entrevistas grabadas en video-Libras y el análisis de los datos constituyó una investigación a través de la observación inicial de la intérprete de Libras y después del profesor. Se constató que dicha evaluación reduce los sentimientos negativos reforzados por la evaluación escrita, favorece la autonomía, la percepción de competencia y de pertenencia, además de ayudar a motivar el proceso de enseñanza y aprendizaje.

PALABRAS CLAVE DISCAPACITAdO AUDITIVO - LIBRAS • EDUCACIÓN INCLUSIVA• EVALUACIÓN DEL APRENDIZAJE.

\section{ABSTRACT}

This article presents a visual assessment, a bilingual proposal for deaf high school students that satisfies the linguistic and educational policy of inclusion. This assessment uses the verbal as well as the non-verbal texts, including visual elements, such as images that refer to the content studied, providing it to deaf students in their own language, the Brazilian sign language. Aspects related to profoundly deaf students, as well as children born to hearing parents, were observed and considered. The observations were registered by means of interviews recorded using video-Libras and the analysis of the data was carried out through the initial observation by the Libras' interpreter and then by the professor. It was noted that this evaluation reduces the negative feelings reinforced by written assessments, favors autonomy and the perception of competence and belonging, helping in the motivation of the teaching and learning process.

KEYWORDS HEARING IMPAIRED • LIBRAS • INCLUSIVE EDUCATION・LEARNING ASSESSMENT. 


\section{INTRODUÇÃO}

A avaliação está, e deve estar, presente em todas as atividades, humanas ou não. Na educação, uma atividade em que se depositam grandes expectativas, as avaliações são parte ainda mais importante do processo. E como prática formalmente organizada e sistematizada, no contexto escolar, realiza-se segundo objetivos implícitos ou explícitos, que, por sua vez, refletem valores e normas sociais (CHUEIRI, 2008). A avaliação não ocorre em momentos isolados, mas está presente em todas as fases do trabalho educativo e reflete a visão política e pedagógica praticada. Caldeira (2000, p. 122) afirma que:

A avaliação escolar é um meio e não um fim em si mesma; está delimitada por uma determinada teoria e por uma determinada prática pedagógica. Ela não ocorre num vazio conceitual, mas está dimensionada por um modelo teórico de sociedade, de homem, de educação e, consequentemente, de ensino e de aprendizagem, expresso na teoria e na prática pedagógica. 
No final, a avaliação se torna uma parte sensível do processo. Não são apenas os professores a avaliar os alunos, os alunos também se avaliam por meio desses instrumentos. Acabam contribuindo para a construção de sua autoimagem. Por isso, a avaliação não pode ser negligenciada e tratada como instrumento de classificação, pois como afirma Luckesi (2000, p. 7):

Muitas vezes, nossos educandos são competentes em suas habilidades, mas nossos instrumentos de coleta de dados são inadequados e, por isso, os julgamos, incorretamente, como incompetentes.

Neste estudo, foram observados e considerados aspectos relacionados apenas aos surdos de grau profundo e filhos de pais ouvintes. É uma realidade mais comum, considerada problemática para os surdos que fazem parte dessa delimitação, pois há falta de inputs ${ }^{1}$ linguísticos na língua de sinais nos membros da família. Muitas vezes, o primeiro contato com a Libras ocorre no âmbito escolar, em escolas polos, que contam com intérpretes de Libras, e no contraturno do atendimento educacional especializado (AEE).

O registro das observações para o presente artigo foi feito por meio de entrevistas gravadas em vídeo-Libras. Os alunos surdos fizeram comentários antes e depois das avaliações visuais em Libras.

Quadros e Cruz (2011, p. 30-31) citam pesquisas sobre aquisição de linguagem entre surdos. Os resultados são divergentes. Na relação sobre a independência da qualidade do input recebido pela criança em sua prática linguística, determinam que a aquisição da linguagem é o que está por trás da expressão linguística, ou seja, são os princípios que regem a aquisição da linguagem, relacionado a algo inato, na proposta inatista da gramática gerativa. No entanto, os autores relatam casos de crianças surdas que, por terem sido expostas tardiamente à língua sinalizada, desenvolveram dificuldades em alguns tipos de construções. Há também uma visível diferença, no nível de desenvolvimento linguístico, entre a trajetória da criança surda filha de pais ouvintes e a da criança surda filha de pais surdos.
1 Input significa entrada; neste contexto, refere-se aos estímulos linguísticos a que as crianças têm acesso, vendo ou ouvindo, na fase crítica de aquisição de linguagem. Nas crianças ouvintes, trata-se do acesso aos estímulos orais auditivos: nas crianças surdas, aos gestos, aos sinais e pantomimas (QUADROS;

CRUZ, 2011, p. 18). 
2 Disponível em: <http://www.ibge gov.br/home/estatistica/populacao/ censo2010/caracteristicas_religiao_ deficiencia/default caracteristicas religiao_deficiencia.shtm>. Arquivo em extensão pdf (publicação completa) disponível em: <http:// biblioteca.ibge.gov.br/pt/bibliotecacatalogo?view $=$ detalhes $\&$ id $=794>$ acesso em: 30 nov. 2015

\section{ALGUNS ELEMENTOS DA DEFICIÊNCIA AUDITIVA}

A surdez é o problema sensorial de maior incidência na população (OMS; BANCO MUNDIAL, 2012). No Brasil, de duas a sete crianças em cada mil nascidas apresentam esse problema (SUGIMOTO, 2002). O Censo $2010^{2}$ (BRASIL, 2012, p. 75) do Instituto Brasileiro de Geografia e Estatística (IBGE) aponta que $5,1 \%$ da população apresenta deficiência auditiva, cerca de 8,5 milhões de pessoas. Esses dados indicam que teremos uma solicitação constante do sistema educativo para atender alunos com esse tipo de necessidade.

Devemos entender que a surdez é uma deficiência que impõe às pessoas dificuldades adicionais, as quais podem ser minoradas com o uso de estratégias mais adequadas a esse público, que tem direitos e que pode contribuir, tanto quanto os ouvintes, para o progresso das sociedades.

\section{POR QUE UMA AVALIAÇÃO DIFERENCIADA?}

Avaliações na modalidade escrita, na língua portuguesa, geram dados insuficientes ou interpretações equivocadas para os alunos surdos. Um método de avaliação padrão, aplicado em uma sala de aula composta majoritariamente por alunos ouvintes, gera frustações aos alunos surdos, pois nem todos eles conseguem ler e compreender o contexto de determinados textos. A grande maioria dos surdos lê palavras isoladas, sem conectivos, tais como artigos, preposições, adjuntos. Por isso, há a necessidade de um intérprete de Libras educacional, profissional que é o canal de mediação entre o professor e o aluno surdo. Entenda-se que esse alunado é bilíngue:

\footnotetext{
Bilinguismo, no caso de surdos, é um conceito específico, relativo a sua condição de deficiência auditiva, a sua língua e a sua cultura. Por estarem inseridos em uma condição bilíngue - língua de modalidades viso-gestual e oral auditiva - e bicultural - cultura da comunidade surda de seu país e cultura ouvinte - entram em um grande dilema referente ao processo de ensino e aprendizagem. (KANASHIRO, 2013, p. 8)
}

Ser bilíngue não é ter fluência em duas línguas. Se há compreensão entre um emissor e um receptor da mensagem, 
houve a competência de comunicação nas línguas envolvidas. No caso, a língua portuguesa, como segunda língua (L2), e a Libras, como primeira língua (L1). Esse processo de bilíngues e biculturais é a forma que encontraram para se ajustar à sociedade majoritariamente constituída por falantes orais da língua portuguesa, mas com certas ressalvas, que seriam, justamente, as estruturas linguísticas envolvidas.

No português, seguimos uma estrutura sujeito-verbo-objeto (SVO), também usada pelo surdo. Mas há uma outra estrutura também usada com frequência, a objeto-sujeito-verbo (OSV). O surdo traz para a frente da frase (fala surda) o objeto (complemento que, em muitos casos, é a referência do "espaço/tempo"). Depois, vem o sujeito e, a seguir, toda a ação do sujeito (verbo, em sua maioria na forma infinitiva, pois muitos surdos, por processos cognitivos linguísticos próprios, não os flexionam). Por isso, a escrita do surdo confunde o professor no momento em que a correção é feita.

Quanto às estruturas gramaticais dos surdos, uma contextualização é dada ao docente pelo profissional intérprete de Libras, ajudando, assim, ambos os lados nessa questão das estruturas linguísticas.

O bilinguismo é uma das propostas para tornar acessíveis ao surdo duas línguas no contexto escolar. Essa proposta é mais adequada para o ensino dos surdos, tendo a língua de sinais como língua natural e, a partir dela, pressupõe-se o ensino da língua escrita. A Libras é uma língua adquirida de forma espontânea pelos surdos em contato com seus pares surdos, que também usam essa língua. Se a língua oral é assimilada de forma sistematizada, então os surdos têm o direito de ser ensinados na língua de sinais. Essa proposta bilíngue busca esse direito (QUADROS, 1997, p. 27).

Apesar de o Instituto Federal de Educação, Ciência e Tecnologia de São Paulo (IFSP), campus Cubatão, disponibilizar uma proposta bilíngue, com inserção do intérprete de Libras e alguns conteúdos de determinada disciplina em vídeo-Libras, além da avaliação visual, houve um longo caminho percorrido pelos surdos da instituição. Foram outras metodologias e propostas de ensino público que não contemplam uma experiência visual a esse alunado, fazendo com 
que eles cheguem ao nível de ensino médio sem o domínio da L2, como é o caso da língua portuguesa.

A surdez em si não é incapacitante. Prova disso é que surdos vêm conquistando seu lugar na sociedade, tanto no trabalho quanto no ambiente escolar. É uma questão de comunicação que, se resolvida ou melhorada, possibilita um desenvolvimento semelhante ao do aluno ouvinte. Na busca dessa solução, a Lei n. 10.436/2002 (BRASIL, 2002) reconhece a Libras como meio legal de comunicação. Diz em seu parágrafo único que:

Entende-se como Língua Brasileira de Sinais a forma de comunicação e expressão em que o sistema linguístico de natureza visual-motora, com estrutura gramatical própria, constitui um sistema linguístico de transmissão de ideias e fatos oriundos de comunidades surdas do Brasil. (BRASIL, 2002)

Com isso, a comunidade surda tem reconhecido que a Libras deve ser ensinada desde a infância como L1 e o português como L2, sendo que a Libras não pode substituir a modalidade escrita da língua portuguesa. Essa legislação é uma conquista importante para os deficientes auditivos, definindo, reconhecendo e apontando garantias de atendimento das necessidades especiais dessa fração da população. O Decreto n. 5.626/2005 (BRASIL, 2005) regulamenta a Lei n. 10.436/2002 (BRASIL, 2002) e o artigo 18 da Lei n. 10.098/2000:

§ 2 Para fins deste Decreto, considera-se pessoa surda àquela que, por ter perda auditiva, compreende e interage com o mundo por meio das experiências visuais, manifestando sua cultura principalmente pelo uso da Língua Brasileira de Sinais - Libras. (BRASIL, 2005)

Em seu capítulo IV, sobre o uso e a difusão da Libras e da língua portuguesa para o acesso das pessoas surdas à educação, a legislação reconhece as necessidades especiais e garante o empenho da rede federal de ensino:

Art. 14. As instituições federais de ensino devem garantir, obrigatoriamente, às pessoas surdas acesso à comunicação, à informação e à educação nos processos seletivos, 
nas atividades e nos conteúdos curriculares desenvolvidos em todos os níveis, etapas e modalidades de educação, desde a educação infantil até a superior. (BRASIL, 2005)

Esse reconhecimento se completa quando a legislação aponta os processos avaliativos, que devem considerar a estrutura linguística desses alunos:
VI - adotar mecanismos de avaliação coerentes com aprendizado de segunda língua, na correção das provas escritas, valorizando o aspecto semântico e reconhecen- do a singularidade linguística manifestada no aspecto for- mal da língua portuguesa. (BRASIL, 2005)

\section{INTERESSE E NECESSIDADE}

Apesar do reconhecimento social e da imposição da lei para a inclusão dos alunos com necessidades especiais, no caso dos alunos surdos, em geral, o ensino se dá por meio de um método voltado à maioria linguística de falantes orais auditivos, o que implica uma defasagem na escolarização dos surdos já no ensino fundamental. Com isso, esses alunos chegam ao ensino médio sem um bom letramento da língua portuguesa e continuam enfrentando situações desfavoráveis.

O IFSP, campus Cubatão, tem na modalidade educação de jovens e adultos (EJA) cinco surdos. São quatro no primeiro ano e um no segundo ano. A inclusão de alunos surdos aconteceu em 2012, com a entrada de dois deles no EJA. Muitos embates aconteceram em sala de aula por desconhecimento dos professores sobre esse alunado, por falta de estrutura para recebê-los, ausência de adaptações de conteúdos escolares e de um profissional intérprete de Libras. Em 2013, foram contratadas duas intérpretes que trabalhavam por contrato de 20 horas, sendo que cada uma trabalhava dois dias e meio na instituição. Não foi uma solução plena, pois ainda faltava um planejamento de aula que ofertasse aos surdos uma experiência visual.

As aulas, dependendo da disciplina, ministradas totalmente na modalidade oral, não proporcionavam um ganho eficiente aos surdos, mesmo com o intérprete educacional em sala. O uso do imagético, ou seja, recursos visuais, poderia ser 
feito, pois algumas salas da instituição contam com projetor e, em outras, televisão ampla. O campo semiótico do aluno surdo, assim, era precário, deixava-o totalmente desconfortável, sem pertencer ao grupo de colegas nem ao processo de ensino e aprendizagem.

Um estado que pode influenciar os resultados das avaliações de todos os alunos, o que inclui os surdos, é o motivacional de cada um, ou seja, o interesse. $O$ interesse se refere a causas internas ou externas do aprendiz ou ao tipo de meta, que podemos designar como motivação intrínseca ou extrínseca. O interesse é um fator pessoal e funciona como elemento regulador, mobilizando a energia necessária, como afirma Piaget (1987, p. 38):

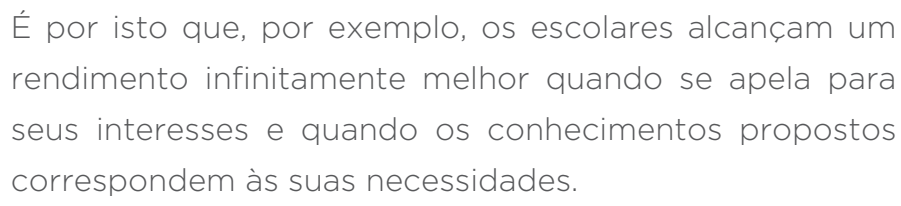

É por isto que, por exemplo, os escolares alcançam um rendimento infinitamente melhor quando se apela para seus interesses e quando os conhecimentos propostos correspondem às suas necessidades.

Analisado com o olhar piagetiano, o interesse está relacionado à motivação intrínseca, pois envolve escolhas do aluno. Visto sob um olhar vygotskiano, o interesse, também envolvendo escolhas pessoais, não deve recair sobre objetos que estão além de suas possibilidades, ou seja, para além da zona de desenvolvimento proximal (VYGOTSKY, 1993). Em ambos os casos, as escolhas pessoais são situações que favorecem a construção e a manutenção de uma autoimagem de competência:

O interesse, este elemento promotor do esforço e dire-
cionador das energias, está intimamente ligado ao valor
que tal conhecimento ou atividade possa representar para
o sucesso do indivíduo. Os interesses estão necessaria-
mente ligados a outras funções afetivas. Segundo Piaget
(1987), aos interesses ou valores relativos estão ligados os
sentimentos de autovalorização, que podem ser entendi-
dos como sentimentos de superioridade e de inferiorida-
de. (SILVA, 2004, p. 20)

Nas diversas atividades humanas, as pessoas apresentam diferentes níveis de interesse que, aliás, também variam no tempo. O interesse, do ponto de vista da Psicologia educacional, pode ser relacionado a causas internas ou externas ou 
ao tipo de meta que orienta o comportamento do aprendiz, os quais podemos designar como motivação intrínseca, motivação extrínseca e metas de realização.

O interesse por alguma atividade está ligado ao potencial de sucesso percebido pelo indivíduo e necessariamente associado a outras funções afetivas. Segundo Piaget (1987, p. 39), o interesse está vinculado a sentimentos de autovalorização e pode representar sentimentos de superioridade e de inferioridade.

A Psicologia da educação também aponta as necessidades como elementos motivadores, criando teorias como a motivação para a competência e a autodeterminação, entre outras, capazes de justificar a motivação intrínseca. Essas necessidades psicológicas, determinantes da motivação intrínseca, foram descritas por Deci e Ryan (1996), Ryan e Deci (2000 3 apud GUIMARÃES, 2001, p. 40) como necessidade de competência, necessidade de autonomia ou autodeterminação e necessidade de pertencer.

Os surdos se encontravam em situação desfavorável em sala de aula. Em comentários deles próprios, diziam que os ouvintes não eram tutelados como eles e lamentavam que sempre precisariam de uma intérprete em sala de aula para compreenderem conteúdos passados pelo professor, já que este não dominava a Libras, necessitando de um canal humano para isso, o intérprete. A falta de autonomia, nesse caso, deve-se à barreira linguística e à necessidade de pertencer ao grupo. Tanto nas conversas com colegas quanto na elaboração de uma simples pergunta ao professor, haveria sempre o impedimento linguístico. Sabe-se que nem só da língua se faz o ato de comunicar. Através de pantomimas também se consegue tal feito, mas não se é completamente compreendido como os atos da fala direta.

A necessidade de competência é a motivação, com destaque para as interações sociais. Na necessidade de autonomia ou autodeterminação, as pessoas acreditam que são responsáveis por seus atos e escolhas e terminam por entender as mudanças e os sucessos como méritos próprios, sentindo-se capazes de fixar metas, planejar ações, avaliar seus progressos e demonstrar acertos e dificuldades. Denomina-se essa
3 RYAN. R. M.; DECI. E. L. Self-determination theory and well-being. American Psycologist, v. 5, n. 1, p. $68-78,2000$. 
pessoa como indivíduo origem - ele é a fonte das mudanças e seus motivos são internos, fazendo dele um indivíduo intrinsecamente motivado (GUIMARÃES, 2001).

A Psicologia da educação também nos diz que metas de realização são posturas do educando durante o processo educativo. A existência de interesse e suas variações de intensidade são também evidenciadas nessas posturas e na orientação às metas de realização assumidas pelos alunos. Entre diversas metas propostas, duas estão bem estabelecidas: a meta performance e a meta aprender. Segundo Schutz (1994, apud BZUNECK, 2001, p. 58), as metas estão entre os mais potentes motivadores do comportamento em geral.

Os alunos orientados pela meta aprender apresentam comportamentos e reações afetivas bem definidas. Para eles, os resultados positivos provêm do próprio esforço e consideram que o sucesso é uma melhora dos conhecimentos e das habilidades. $\mathrm{O}$ êxito dá origem a sentimentos de orgulho e satisfação. Erros e fracassos são entendidos como elementos informativos presentes no processo de aprendizagem (BZUNECK, 2001).

A meta performance dá maior valor ao resultado que à aprendizagem. Por isso, pode ser vista de forma negativa, uma vez que o aprendiz deseja bons resultados que comprovem sua inteligência, mas nem sempre os alcança. Nesse caso, a preocupação é não se mostrar incapaz e, quando ocorre alguma falha, o aluno considera que decorre da própria incapacidade, apresentando emoções negativas. Por outro lado, na ausência da meta aprender, a meta performance pode ser positiva, já que o desejo de uma boa realização desta pode favorecer o esforço e o uso de estratégias de aprendizagem (PINTRICH; SCHUNK, 1996). Em virtude dessas duas possibilidades, a meta performance foi dividida em duas frentes - a meta performance-aproximação e a meta performance-evitação. A primeira compreenderia, por exemplo, a busca por parecer inteligente, ao passo que a segunda se encarregaria da tentativa de não aparecer como incapaz.

Em relação aos surdos incluídos no EJA, percebíamos o grande interesse deles em copiarem os conteúdos e até a entrega de atividades na modalidade escrita, não importando 
se haviam compreendido ou não, mas pelo simples fato de garantir a nota, como todos os outros alunos ouvintes. Os professores ficavam confusos porque havia grandes diferenças na escrita dos surdos nas atividades de sala de aula em grupo, ou atividades para serem feitas em casa, comparando-se com as escritas das provas presenciais. Nas atividades de grupo e de casa, a escrita estava no português padrão e nas provas presenciais era um português diferenciado, desconhecido pelos docentes, com outra estrutura linguística, sem conectivos (artigos, adjuntos, preposições), verbos no infinitivo, entre outras diferenças. Era a escrita do surdo. Enquanto os alunos ouvintes ajudavam os surdos nas atividades extras, deixavam que copiassem seus conteúdos, ato esse que não permitia assimilar o aprendizado. Já nas provas, os surdos as faziam com sua própria escrita.

Surdos não têm o costume de estudar em casa, pois, em sua maioria, são filhos de pais ouvintes que desconhecem a língua de sinais. Não haveria uma comunicação efetiva no lar ou na vizinhança, para se passar os conteúdos de sala de aula, sanar dúvidas e ajudar a compreender o que estava escrito tanto no caderno, na apostila digitalizada, quanto no livro didático.

\section{O PROCEDIMENTO METODOLÓGICO}

Foi observado que os parâmetros usados para avaliar os alunos ouvintes não atingiam da mesma maneira os alunos surdos. O ouvinte, em dia de avaliação, recebia a prova escrita sem fotos ou qualquer referência a um texto não verbal. Fazia a leitura silenciosa de forma autônoma e, a partir de suas inferências, começava a expor seus pensamentos na forma de escrita da língua portuguesa. Dos alunos surdos, três possuíam uma base do português, mas não dominavam todas as técnicas de letramento. Ao tentarem reconhecer os gêneros textuais, ficavam confusos, pois a Libras, língua natural deles, e a língua portuguesa não são semelhantes em alguns aspectos, como os conectivos: preposições, adjuntos, artigos. Além disso, não flexionavam o tempo verbal adequadamente, pois, por processos cognitivos linguísticos, a Libras não 
flexiona o tempo do verbo; isso ocorre através dos advérbios de tempo ou marcadores de tempo incorporados aos verbos na Libras, que direcionam a ação do verbo para o tempo desejado no discurso do surdo. Fica difícil para eles entender um texto, linha a linha, na língua portuguesa (QUADROS, 2008, p. 262).

Se as provas escritas fossem adaptadas à estrutura da Libras, quebrar-se-ia esse estigma de o surdo não se sentir confortável em ler algo que ele "acha" que é, mas não tem certeza ou não confia no que lê. Tem sempre que ficar esperando a interpretação das mãos da intérprete de Libras após a leitura silenciosa da prova. Esse "achismo" gera desconforto, desmotiva e desconecta o surdo da rotina de um dia de prova. Veem os ouvintes independentes com provas sobre a carteira e eles mesmos, os surdos, ficam à mercê de uma outra pessoa (intérprete) para compreensão dos conteúdos. Outro fator desfavorável na modalidade escrita, mesmo que na estrutura da Libras, é que nem todo surdo lê e compreende as glosas em português e encontra uma analogia na língua de sinais. O léxico da língua portuguesa é bem mais vasto que o da língua de sinais. Novamente, o surdo necessitaria de um fator externo para compreensão, como um dicionário ou um intérprete para esclarecimento.

Já com o único aluno monolíngue, a sensação de desconforto era pior. Ele dava de ombros, apontava para o papel, expressava descontentamento, olhava para os lados e via outros colegas surdos tentando ler e escrever. A incapacidade de ler o que estava no papel a sua frente deixava-o com vergonha perante os amigos surdos, os colegas ouvintes e todos os que estavam na sala.

Buscando entender que resultados uma avaliação diferenciada poderia produzir nos alunos com deficiência auditiva, uma plataforma de avaliação foi pensada e construída com a HyperText Markup Language (HTML), ${ }^{4}$ possibilitando independência e autonomia de resolução equivalentes ao aluno ouvinte, deixando-o ir e vir entre as questões e as alternativas. A plataforma apresenta sempre um sinal imagético, relacionado à questão, para uma fácil analogia com os conteúdos trabalhados em sala de aula. Também há os sinais em Libras, convencionados durante uma explicação de conteúdo entre 
intérprete de Libras, professor e o próprio aluno surdo durante as aulas presenciais. Para esse aluno, é a imagem o elemento principal de aquisição da informação. O mais importante é que, além do texto escrito, a avaliação visual apresenta instruções, questões e alternativas na Língua Brasileira de Sinais.

FIGURA 1 - Layout da plataforma para avaliação visual

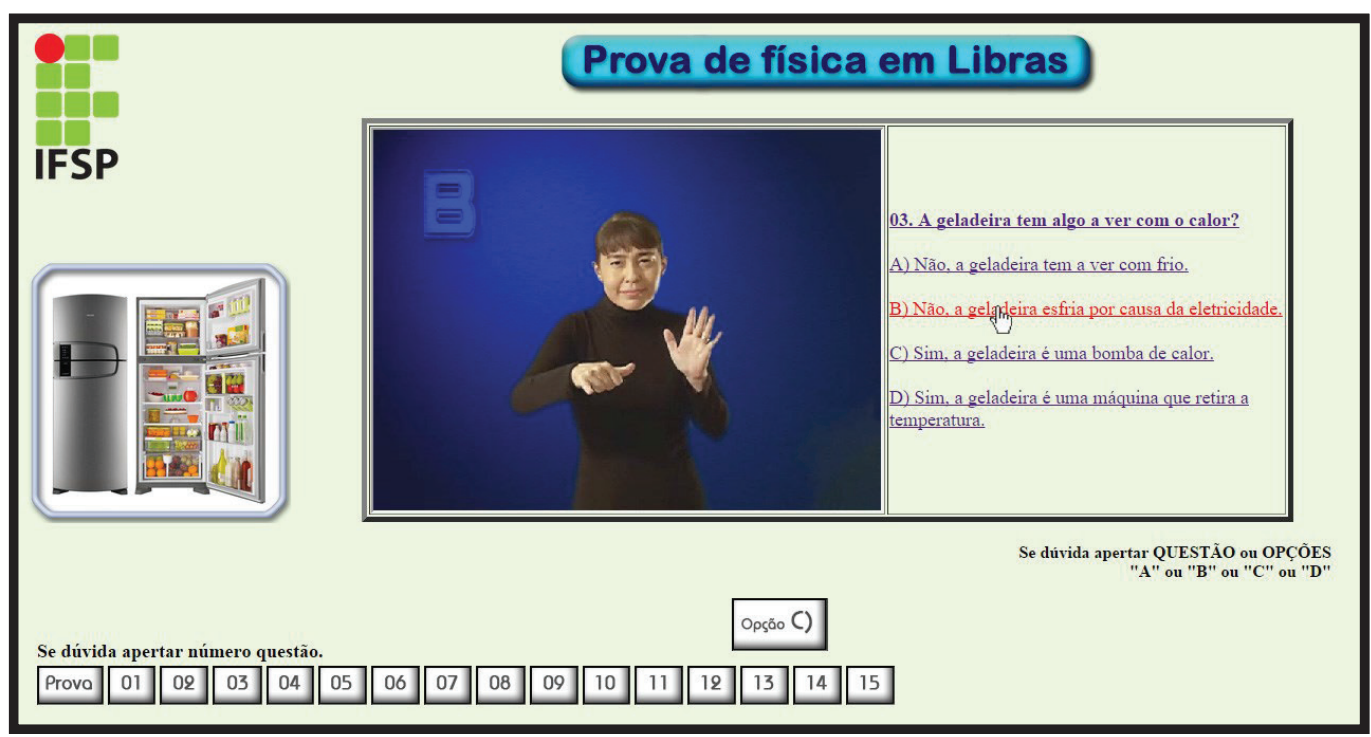

Fonte: Versão 3 da prova de vídeo-Libras.

O trabalho foi desenvolvido com um grupo de quatro alunos surdos, todos maiores de 18 anos e matriculados no primeiro ano do EJA, durante o curso de Física Básica. Um dos alunos só consegue, praticamente, comunicar-se em Libras. Não foi alfabetizado no período regular de ensino fundamental e apresenta um déficit de aprendizagem de linguagem. Esse aluno monolíngue fez implante coclear em fases diferentes da infância e pré-adolescência, mas não usa a presilha externa para captação dos sons, que seriam repassados para os eletrodos implantados no canal da cóclea. Por isso, acaba sendo um surdo profundo como os demais colegas surdos de classe. Todos os alunos observados encontram-se no primeiro ano do EJA integrado à informática do IFSP, campus Cubatão. 
A coleta de dados da pesquisa se deu em diversos momentos, pontuais e amplos. Dois desses momentos pontuais foram em duas provas bimestrais, quando os alunos receberam as mesmas provas dos alunos ouvintes e foram apresentados à plataforma. Nela, a intérprete anuncia, através de vídeos, as questões, explica a pergunta e cada uma das alternativas. Depois disso, o aluno aponta sua resposta na folha de prova. Enquanto eles trabalhavam, eram observados pelos pesquisadores. Outros dois momentos pontuais foram os pós-provas.

Nas provas escritas, entrevistas foram feitas pela intérprete no pós-prova. Os alunos surdos foram questionados se a prova estava difícil, se os conteúdos estavam claros para eles e se havia algo que eles gostariam de expor. Todos diziam que o problema maior era compreender o que estava escrito em português e que a dificuldade é principalmente gerada porque surdos não têm o hábito de estudar em casa por falta de alguém que domine a Libras para esclarecimentos sobre os conteúdos das apostilas. Ficar olhando somente fotos nas apostilas não ajuda a contextualizar, por isso eles ficavam nos "achismos" de sempre. Não confiavam no que liam em português e, por esse motivo, não faziam muito esforço para os momentos amplos que a educação exige de um aluno.

Os momentos amplos, aqui subentendidos, são aqueles em que o aluno desperta para o ato de estudar fora da sala de aula. Isso pode ocorrer em uma pesquisa na internet, na resolução de uma atividade extra solicitada pelo professor para ser feita no lar, em um resumo dos conteúdos da aula presencial, sempre com o apoio da apostila. $\mathrm{O}$ aluno se veria como detentor do conhecimento, do processo de aprendizagem, no momento em que se deparasse com o primeiro obstáculo, que poderia ser uma dúvida em um cálculo matemático, no conceito de uma palavra desconhecida ou ao consultar um dicionário para esclarecer de forma autônoma sua dúvida. Ao transpor esse obstáculo, esse aluno vai assimilando e galgando degraus de maturação do conhecimento.

[...] a operação só pode surgir da representação com significado, ou seja, aquela que representa a ação, ou a 
experiência que se estruturou graças a essa ação. [...] É nesse sentido, que o mundo da natureza para Freire passa a ser mundo da cultura: a ação do homem operou esta transformação. Impõe-se, aqui, mais do que a tomada de consciência (Piaget), a conscientização (Freire), para que este mundo da cultura não seja arrebatado das mãos do sujeito cuja ação o produziu. [...] Aqui a aprendizagem no sentido estrito assumirá especial importância devido à interferência direta e maciça da escola no processo de desenvolvimento e, por isso mesmo, uma aprendizagem enriquecida por aquisições mediatas por meio da indução; ao mesmo tempo, o processo de equilibração será enriquecido pela inferência, não mais transdutiva ou pré-conceptual, mas dedutiva. (BECKER, 2011, p. 16, grifo nosso)

Com o aluno surdo, esses momentos amplos não se finalizam na resolução da dúvida e dos questionamentos pelo simples fato da existência de uma barreira linguística. A língua dos livros, das apostilas, dos dicionários, das questões matemáticas é uma língua majoritariamente falada por uma população oral auditiva na língua portuguesa. Há poucos materiais em Libras de disciplinas específicas, como é o caso da disciplina de Física. Skliar (2010, p. 22) afirma que esses exemplos servem para demonstrar critérios quantitativos para uma política educacional, que se tornam necessariamente qualitativos e respondem a uma hierarquia e a uma assimetria de poderes:

A utilização da língua de sinais por parte dos surdos é, por

si, o fato que melhor sublinha esse conjunto de relações assimétricas de poder e evidencia aquilo que a maioria (minoria) ouvinte quer desterrar das escolas de surdos: a surdez.

Para a confecção das avaliações visuais em Libras, a intérprete entrou em contato com profissionais da Universidade Estadual de Campinas (Unicamp), que forneceram um trabalho de mestrado de alunos de Matemática da Universidade Federal de Mato Grosso do Sul (UFMS), juntamente com intérpretes e surdos daquele estado, com sinais convencionados para as disciplinas de Física, Mecânica e Cinemática. Foram 
horas de pesquisa e estudos de sinais específicos, utilizados em sala de aula para que os alunos surdos se apropriassem dos novos sinais durante as aulas de Física. Após os primeiros meses de aula, os alunos surdos foram adquirindo sinais em Libras, com atividades resolvidas em sala de aula. A partir daquele momento, o trabalho foi sendo feito em tempo real, para assimilação dos conteúdos e dos sinais, melhorando o aproveitamento da hora-aula presencial. Apesar de insuficiente, foi o modo para poder usar esse aproveitamento nas questões das avaliações visuais em vídeo-Libras. Os vídeos-Libras da avaliação visual eram analisados por um ex-aluno surdo do IFSP, fluente em Libras, acostumado com a metodologia do professor e da disciplina de Física, em parceria com a intérprete de Libras.

\section{A ANÁLISE DOS DADOS}

Todo o material foi transcrito. A análise desses dados se constituiu como um estudo de caso, uma investigação através da observação inicial da intérprete de Libras e depois do próprio professor da disciplina de Física, sobre um tema bastante específico e concreto, tomada em observações diretas em seu ambiente natural (YIN, 2005; STAKE, 1999). Além das impressões dos alunos e dos pesquisadores, os resultados das avaliações foram comparados com os anteriores e com a média dos alunos ouvintes, tentando, à luz de nosso referencial teórico, encontrar alguma influência da avaliação visual.

$O$ processo de aprendizagem dos alunos envolve uma ampla gama de fatores - internos, externos, sociais, estruturais e ambientais. A motivação é um desses fatores que precisam ser considerados para todos os aprendizes. Porém, quando tratamos da educação do aluno com surdez, esse fator ganha maior relevância. Esse aluno, por sua condição especial, enfrenta dificuldades adicionais e, em virtude disso, sua autoestima e percepção de competência podem sofrer sérios abalos.

De forma geral, nossa pergunta é: como a realização de uma avaliação visual pode impactar a motivação desses alunos?

Para a análise do material, procuramos encontrar, nas falas dos alunos e nas observações dos pesquisadores, 
elementos motivadores e desmotivadores, que possivelmente influenciam o comportamento dos aprendizes.

Um primeiro resultado que podemos perceber é o das provas. Na primeira prova bimestral - uma avaliação dissertativa para alunos ouvintes -, os alunos surdos não conseguiram expressar seu aprendizado, obtendo um resultado nulo. Nos bimestres seguintes, eles realizaram a avaliação visual e os números puderam expressar seu estado do aprendizado, conforme se depreende da Tabela 1.

TABELA 1 - Resultado das provas bimestrais de Física dos alunos surdos - 2014

\begin{tabular}{|c|c|c|c|c|}
\hline ALUNO & BIMESTRE 1 & BIMESTRE 2 & BIMESTRE 3 & BIMESTRE 4 \\
\hline 1 & 0 & 4,5 & 4,0 & - \\
\hline 2 & $\mathrm{O}$ & 3,5 & 3,4 & - \\
\hline 3 & 0 & 4,0 & 1,4 & - \\
\hline 4 & 0 & 4,5 & 4,7 & - \\
\hline
\end{tabular}

Fonte: IFSP Cubatão.

Na Tabela 1, podemos apreciar a situação de forma diferente. No primeiro bimestre, os resultados foram muito ruins e não se pôde saber nada sobre o aprendizado dos alunos. Nos bimestres seguintes, os resultados não foram bons, mas são uma expressão palpável do que eles puderam fazer e, o mais importante, eles relatam que a avaliação estava fácil e que, se tivessem estudado mais, obteriam melhores resultados. A primeira não serviu para nada, mas as duas seguintes, além de informar o professor, informaram também os alunos.

Detidos no estudo das transcrições, procuramos elementos motivadores e desmotivadores e os agrupamos em nossas categorias conceituais - autovalorização, necessidade de competência, necessidade de autonomia, necessidade de pertencer, meta aprender, meta performance-aproximação e meta performance-evitação. Esses elementos se referem à experiência do aluno surdo com a avaliação tradicional e com a avaliação visual, além das próprias impressões dos pesquisadores.

De forma geral, não encontramos elementos desfavoráveis à avaliação visual, apenas observações para melhoria, que só poderiam vir dos usuários surdos. A datilologia ${ }^{5}$ é apontada 
como recurso a ser evitado, uma vez que se aproxima da linguagem escrita e, por vezes, não tem significado para o aluno surdo.

\section{AUTOVALORIZAÇÃO}

Nos alunos surdos, a limitação auditiva impõe comportamento mais tenso durante as avaliações. Mas durante e depois da avaliação visual, eles se comportaram como alunos, somente alunos. A postura na sala de aula mudou, as expressões faciais mudaram para melhor e eles pareciam estar no controle da situação. Depois da avaliação, como acontece com praticamente todos os alunos que realizam um teste, eles também saíram conversando sobre a prova, discutindo as razões que levaram à escolha dessa ou daquela alternativa, tentando resgatar os conceitos e as explicações da sala de aula.

Esse efeito positivo aparece mais intensamente para o aluno monolíngue, que não se expressa em português. Como precisa de maior atenção da intérprete, ele já se habituou a ser o último e se sente totalmente desconfortável com as avaliações tradicionais. Com a avaliação visual, seu comportamento foi muito diferente. Pela primeira vez, ele se comportou como um igual. A avaliação visual o colocou em pé de igualdade com os demais alunos surdos, além de não provocar o desconforto de monopolizar a intérprete, prejudicando o atendimento aos outros. Esteve tranquilo e realizou sua avaliação com a mesma destreza dos outros alunos.

De forma geral, a avaliação visual apareceu como um elemento de respeito e consideração. Os alunos estavam recebendo algo preparado para eles, na linguagem natural deles, o que nos revelou algo incrível - dessa vez, eles entenderam que só havia uma alternativa certa.

\section{POR QUE NÃO A PROVA ESCRITA?}

Ao contrário da prova em Libras, a avaliação escrita reafirma as diferenças, fato observado na fala de um dos alunos em Libras: "ouvintes precisar não intérprete Libras. Ouvinte saber 
ler papel prova. Surdo burro. Entender não prova escrita”. A prova escrita gera desconforto e constrange os alunos, pois percebem que o professor não entende o que escrevem. Eles escrevem como falam e pensam, em uma estrutura diferente da utilizada pelos ouvintes. A prova escrita fomenta a dependência, aumentando sempre a importância da intérprete, e reduz a autovalorização dos alunos, pois, de antemão, já sabem que não conseguirão realizar nem entender o que se pede. Nesse grupo, um dos alunos começou a fugir das aulas e da escola em dias de prova, tamanho o desconforto experimentado por ele.

Agora, um episódio relatado desses momentos. O prédio do IFSP tem dois andares; o EJA ocupa duas salas do segundo andar. Quando termina a aula, todos descem a rampa e, em dias de provas, os ouvintes discutem sobre uma ou outra questão da prova. Com os surdos, parecia que o silêncio característico deles se acentuava com os rostos de decepção por não terem conseguido fazer a prova na modalidade escrita. Os que escreviam nem sempre conseguiam encontrar as palavras para expressar o que realmente diziam com as mãos em Libras, ficavam confusos. Procuravam e perguntavam à intérprete como escrever tal palavra, pois diziam querer agradar ao professor na hora de ele ler as respostas e, com isso, não se prejudicarem na nota por causa da escrita diferenciada.

A intérprete, apesar dos esforços, dizia que o professor aceitaria o modo como se expressassem em português, mas não os convencia, sendo que o tempo hábil de duas horas-aulas era insuficiente para responder nem mesmo metade da prova.

A prova escrita reforça o sentimento de inferioridade e a dependência - os alunos esperam sempre pela intérprete e se sentem menos capazes por sua dificuldade com o português. A prova serve sempre de comparação entre os alunos e eles percebem a diferença do próprio trabalho em relação aos ouvintes. O constrangimento é tanto que eles dizem que gostariam de ser como os alunos ouvintes: "eles (ouvintes) inteligentes. Precisar não intérprete libras. Prova fazer sozinho. Nós (desejo de ser) igual ouvintes". 
A avaliação escrita não deve ser usada com os alunos surdos porque eles não conseguem entender e se expressar em português. Somente essa limitação já inviabiliza esse tipo de avaliação, até mesmo para efeitos de classificação, além de não oferecer qualquer elemento diagnóstico sobre o aprendizado.

Além disso, ela impõe tantos sentimentos negativos que a motivação intrínseca fica prejudicada, sendo possível que o comportamento em relação à avaliação se estenda aos dias de aula, uma vez que os surdos já sabem que não poderão obter sucesso nas avaliações futuras.

\section{NECESSIDADE DE COMPETÊNCIA}

De forma geral, os aprendizes se esforçam para controlar seu espaço e seu meio, para serem competentes. Os alunos surdos também. As avaliações tradicionais não os favorecem, uma vez que estão expressas em uma língua que eles não dominam plenamente, o que, sem dúvida, reduz as possibilidades de sucesso.

Com a avaliação visual, eles entenderam as questões entenderam o que se perguntava e o que se queria que eles fizessem. Não perderam partes da interpretação por conta da maior ou menor agilidade desse ou daquele aluno e puderam apreciar todas as descrições. Em virtude disso, a avaliação visual permitiu uma apreensão em primeira ordem, uma interpretação preparada anteriormente e que cada um poderia ver e rever, da mesma forma, quantas vezes fossem necessárias - assim como faz um aluno ouvinte ao ler e reler as questões.

A avaliação visual, realizada como prova de múltiplas escolhas, foi percebida como um elemento positivo. Ao integrar diversos elementos, como figuras, textos e interpretação em Libras, além de facilitar o entendimento do aluno, evitou também que sua dificuldade de expressão na língua escrita prejudicasse a qualidade das respostas que cada um poderia oferecer. Eles relataram que as questões não eram difíceis, embora não soubessem as respostas. Conseguiram perceber que precisavam estudar mais e apontaram que a apostila não os ajudava. 
Algo observado na primeira versão da avaliação visual foi que os surdos ficaram assustados, mas ao mesmo tempo alegres por não precisarem realizar a avaliação escrita. Não tinham a autonomia de escolher o tempo que cada um levaria para responder às questões, pois a intérprete, com um notebook conectado a um projetor, de onde exibia as questões, tinha que esperar todos terminarem a mesma questão para passar para a próxima. Com isso, os mais rápidos para responder acabavam influenciando os mais lentos, pressionando-os na escolha de uma alternativa como resposta. Isso foi um ponto negativo. Na segunda versão, esse problema ainda não havia sido solucionado. Mas um outro foi ajustado, a escolha aleatória do vídeo-Libras das alternativas. Na primeira versão, caso um aluno quisesse rever uma alternativa, seria necessário chegar a ela passo a passo, não diretamente. Se um aluno surdo pedisse para voltar ao vídeo da alternativa "A" e a intérprete já estivesse na alternativa "D", o retrocesso teria que ser feito sequencialmente, indo para a alternativa "C", depois para a "B" até chegar à "A", o que gerava impaciência nos surdos.

Tudo isso foi solucionado na terceira versão. Além disso, as provas da avaliação visual foram rodadas nos computadores do laboratório de informática do IFSP, não mais através de um projetor. Cada aluno sentou em lugares bem distantes um do outro para que não se comunicassem durante a prova. Cada um, de forma autônoma, fez a prova em tempos estimados diferentes. Até o aluno monolíngue quis gravar a entrevista tanto antes de começar a prova quanto depois. Foi somente nessa terceira versão da avaliação visual que conseguimos uma entrevista em que ele realmente quisesse se manifestar. Disse em Libras: "eu ver computador" [apontou para a tela e para a avaliação visual], “depois eu lápis marcar resposta prova papel. Eu pensar pensar pensar só, depois resposta marca papel".

Os outros surdos disseram ser muito melhor a prova no laboratório de informática. Cada um fazendo a seu tempo, pois assim não teriam que esperar todos terminarem a mesma questão. Poderiam voltar quantas vezes quisessem aos vídeos-Libras da avaliação, sem se preocuparem com o colega 
surdo ao lado, evitando a "cola", o que acontece quando estão muito próximos na sala de aula normal.

E no final dessa prova notou-se o que foi relatado em seção anterior, "Por que não a prova escrita?", quando se descrevem as conversas pós-prova. Naquele momento, os surdos se transformaram em alunos que ultrapassaram as fronteiras da sala de aula presencial. Discutiam os conteúdos porque se lembravam das questões em sua língua natural e de conforto. As barreiras linguística e atitudinal foram ultrapassadas. Foi através da avaliação visual que descobrimos que esses alunos poderiam, sim, ser motivados, por meio de sua língua de expressão e compreensão de mundo, a Libras.

Deixaram de ser tutelados pela intérprete de sala de aula para se tornarem independentes na hora da prova. Estavam confiantes em seu próprio progresso pessoal.

\section{NECESSIDADE DE AUTONOMIA}

A autonomia dos alunos é um desejo de todos, não só deles. Acreditar que empreende por vontade própria e não por determinação de agente externo pode ser um grande promotor da motivação intrínseca.

Nesse caso, a avaliação visual foi ainda melhor. Os alunos não precisavam mais da intérprete para compreender as questões, e o aluno monolíngue sentiu a situação com maior intensidade. Além disso, a prova promoveu a independência quando ofereceu a tranquilidade de ir e vir, além dos elementos visuais, deixando os alunos mais seguros. Eles disseram: "prova Libras suave! Muito melhor prova assim Libras". A avaliação visual operada pessoalmente aproxima ainda mais as condições do aluno surdo da dos alunos ouvintes, colocando sob controle de cada um o ritmo e o andamento da prova, em relação ao tempo disponível.

\section{NECESSIDADE DE PERTENCER}

Esses alunos surdos não enfrentam dificuldades de relacionamento no ambiente escolar, eles são um pequeno grupo bem aceito pelos colegas. Entretanto, isso não é 
suficiente. São alunos e querem conseguir resultados, no mínimo, semelhantes aos dos outros, querem perceber que a instituição se importa com eles.

A avaliação visual atua também nesse sentido quando apresenta ao aluno um produto preparado exclusivamente para ele, pensado para ele, transmitindo a ideia de que nos importamos com ele e que estamos trabalhando para que possa aproveitar o curso tanto quanto os alunos ouvintes. O resultado também é importante, o desejo de conseguir se expressar e ter notas semelhantes às notas dos alunos ouvintes. Integrando tudo isso, pode reforçar a sensação de que o surdo faz parte do grupo e do lugar.

Pertencer a um grupo pressupõe algum grau de igualdade e cumplicidade, algo que não é favorecido por um elemento que reforça a inferioridade dos surdos em relação aos ouvintes. Ao valorizar a escrita, os surdos se sentem desprestigiados, pois percebem que a Libras não tem o mesmo status que o português. Como se sentir parte se não se consegue fazer o que os outros fazem?

\section{METAS APRENDER, PERFORMANCE-APROXIMAÇÃO E PERFORMANCE-EVITAÇÃO}

Os dados que obtivemos não nos forneceram elementos que evidenciassem alguma capacidade da avaliação visual em favorecer uma orientação dos alunos para a meta aprender ou para a meta performance-aproximação. Embora seja evidente a preferência por esse modelo de prova, nada sugere que o comportamento frente ao trabalho de aprender venha a sofrer alguma alteração no sentido dessas metas. No entanto, a avaliação visual pode reduzir ou desestimular um comportamento de evitação, já que essa forma de avaliação favorece o entendimento, a compreensão e a expressão dos alunos surdos.

\section{REFLEXÕES GERAIS}

A avaliação visual altera profundamente o ambiente de avaliação para os alunos surdos. Ao proporcionar-lhes independência da intérprete, permite que cada um se concentre 
mais na construção de suas respostas. Quanto às dúvidas no decorrer da prova, esse modelo também equipara o aluno surdo ao ouvinte: o professor pode avaliar se responde para todos ou apenas para quem tem a dúvida, evitando paradas e aportes desnecessários, que podem até atrapalhar o raciocínio ou o desempenho dos demais.

A avaliação visual, além de servir como instrumento de classificação, serve também como oportunidade de estudos para o aluno surdo. Ao combinar imagens com a interpretação dos textos, favorece a aquisição de significado para as palavras em português ou na datilologia.

\section{CONCLUSÕES}

As conclusões expostas neste trabalho advêm de um caso específico, por isso algumas delas podem não ser aplicáveis a outros grupos de alunos surdos. Outros grupos podem ser mais bem alfabetizados em português e enfrentar melhor uma avaliação escrita, comprometendo algumas de nossas afirmações.

No entanto, nosso estudo apresenta uma clara vantagem para o professor e para os alunos com surdez, pois podem se valer de uma metodologia de avaliação visual. Nesse caso, o processo de avaliação pode ser informativo e diagnóstico, além de classificatório.

Outra vantagem incontestável é que a avaliação visual, por ser apresentada na língua natural desses alunos, reduz os sentimentos negativos reforçados pela avaliação escrita. Entre outras vantagens, ela favorece a autonomia, a percepção de competência e a percepção de pertencimento.

A avaliação visual diz claramente ao aluno que ele é parte importante do processo e que o produto foi feito e pensado para ele. Ser avaliado em um procedimento claro e compreensível, que permita ao aluno expressar seu entendimento, apesar de sua limitação com a língua escrita, pode ser um potente promotor da motivação, favorecendo todo o processo de ensino e aprendizagem.

Não fossem esses elementos suficientes para recomendar a utilização da metodologia visual para a avaliação dos alunos surdos, poderíamos nos fiar apenas nos melhores 


\section{ideais de solidariedade e justiça, de oferecer a cada um não apenas a oportunidade, mas as condições de aproveitar essas oportunidades, respeitando as dificuldades e as limitações de cada ser humano.}

\section{REFERÊNCIAS}

BECKER, F. O caminho da aprendizagem em Jean Piaget e Paulo Freire: da ação à operação. 2. ed. Petrópolis, RJ: Vozes, 2011.

BRASIL. Decreto n. 5.626, de 22 de dezembro de 2005. Regulamenta a Lei n. 10.436, de 24 de abril de 2002, que dispõe sobre a Língua Brasileira de Sinais Libras, e o art. 18 da Lei n. 10.098, de 19 de dezembro de 2000. Disponível em: <www.planalto.gov.br/ccivil_03/_ato2004-2006/2005/decreto/d5626. htm>. Acesso em: 23 jul. 2014.

BRASIL. Lei n. 10.436, de 24 de abril de 2002. Dispõe sobre a Língua Brasileira de Sinais - Libras e dá outras providências. Disponível em: <www.planalto.gov. br/ccivil_03/leis/2002/110436.htm>. Acesso em: 23 jul. 2014.

BRASIL. Instituto Brasileiro de Geografia e Estatística. Censo demográfico 2010. Resultados gerais da amostra. Rio de Janeiro: IBGE, 2012. Disponível em: <www.ibge.gov.br/home/presidencia/noticias/imprensa/ppts/0000000847310 4122012315727483985.pdf>. Acesso em: out. 2014.

BZUNECK, J. A. A motivação do aluno orientado a metas de realização. In: BZUNECK, J. A.; BORUCHOVITCH, E. (Org.). A motivação do aluno: contribuições da Psicologia contemporânea. Petrópolis, RJ: Vozes, 2001. p. 58-77.

CALDEIRA, A. M. S. Ressignificando a avaliação escolar. In: COMISSÃO PERMANENTE DE AVALIAÇÃO INSTITUCIONAL UFMG-PAIUB. Belo Horizonte: PROGRAD/UFMG, 2000. p. 122-129 (Cadernos de Avaliação, 3).

CHUEIRI, M. S. F. Concepções sobre a avaliação escolar. Estudos em Avaliação Educacional, São Paulo, v. 19, n. 39, p. 49-64, jan./abr. 2008.

DECI, E. L.; RYAN, R. M. Need satisfation and the self-regulation of learning. Learning \& Individual Diferences, v. 8, n. 3, p. 165-184, 1996.

GUIMARÃES, S. Motivação intrínseca, extrínseca e o uso de recompensas em sala de aula. In: BZUNECK, J. A.; BORUCHOVITCH, E. (Org.). A motivação do aluno: contribuições da Psicologia contemporânea. Petrópolis, RJ: Vozes, 2001.

KANASHIRO, E. H. T. Bilinguismo: português e Libras. Práticas pedagógicas no ensino dos alunos surdos em escola regular pública. Monografia (Pós-graduação em Libras e Educação de Surdos) - Faculdades Integradas Espírita, Projeto Unibem, 2013.

LUCKESI, C. C. O que é mesmo o ato de avaliar a aprendizagem. Pátio, v. 3, n. 12. Porto Alegre: Artmed, fev./abr. 2000. Disponível em: <www.nescon. medicina.ufmg.br/biblioteca/imagem/2511.pdf>. Acesso em: 7 out. 2014. 
ORGANIZAÇÃO MUNDIAL DA SAÚDE; BANCO MUNDIAL. Relatório mundial sobre a deficiência. São Paulo: SEDPcD, 2012.

PIAGET, J. Seis estudos de Psicologia. 15. imp. Rio de Janeiro: Forense Universitária, 1987.

PINTRICH, P. R.; SCHUNK, D. H. Motivation in education, theory, research and application. Englewoods Cliffs: N. J. Prentice Hall, 1996.

QUADROS, R. M. de. Educação de surdos: a aquisição de linguagem. Porto Alegre: Artmed, 1997.

(Org.). Estudos surdos III. Petrópolis, RJ: Arara Azul, 2008.

QUADROS, R. M. de; CRUZ, C. R. Língua de sinais: instrumentos de avaliação. Porto Alegre: Artmed, 2011. v. 1.

SILVA, E. L. da. Aspectos motivacionais em operação nas aulas de Física do ensino médio, nas escolas estaduais de São Paulo. Dissertação (Mestrado em Ensino de Ciências) - Universidade de São Paulo, São Paulo, 2004.

SKLIAR, C. (Org.). A surdez: um olhar sobre as diferenças. 4. ed. Porto Alegre: Mediação, 2010.

STAKE, R. E. Investigación con estudio de casos. Madrid: Morata, 1999.

SUGIMOTO, Luiz. Mal remediável. Jornal da Unicamp, n. 183, 30 jul./ 3 ago. 2002. Disponível em: <www.unicamp.br/unicamp/unicamp_hoje/ju/julho2002/ unihoje_ju183pag12.html>. Acesso em: out. 2014.

VYGOTSKY, L. S. Pensamento e linguagem. São Paulo: Martins Fontes, 1993.

YIN, R. Estudo de caso: planejamento e métodos. Porto Alegre: Bookman, 2005.

\section{ELIFAS LEVI SILVA}

Professor Doutor do Instituto Federal de Educação, Ciência e Tecnologia de São Paulo (IFSP), Cubatão, São Paulo, Brasil elifas_levi@ifsp.edu.br

\section{ELAYNE KANASHIRO}

Professora de Libras do Instituto Federal de Educação, Ciência e Tecnologia de São Paulo (IFSP), Cubatão, São Paulo, Brasil. Graduanda de Licenciatura em Letras-Libras da Universidade Federal da Grande Dourados (UFGD), Dourados, Mato Grosso do Sul, Brasil

kanashiroelayne@ifsp.edu.br 
